\title{
Toplumda Eşcinsellere Yönelik Tutumlar ve Lezbiyen Kadınlarda Sağlık Eşitsizliği
}

\author{
Attitudes Towards Homosexuals in Society, and Health Inequalities Regarding \\ Lesbian Women
}

\author{
Nevin HOTUN ŞAHİN ${ }^{\mathrm{a}}$, Dilek BİLGIÇ
}

\begin{abstract}
ÖZET Dünyada eşcinsellere yönelik tutumlar değişmeye, lezbiyen ve aileleri konusunda toplumun farkındalığı artmaya, eşcinsellik kabul edilebilir bir yaşam stili olarak daha fazla görülmeye başlamıştır. Buna karşın yine de heteroseksüel kadınlarla kıyaslandığında lezbiyen kadınlar gerek koruyucu sağlık hizmetlerin kullanımında gerekse sağlık bakım hizmetlerinden yararlanmada önemli düzeyde eşitsizlikler yaşayan, büyük ölçüde ayrımcıllğa maruz kalan bir gruptur. Lezbiyen kadınlar çoğunlukla hemşire ve diğer sağlık profesyonelleri arasında açığa çıkma korkusu ve homofobik tutumlardan dolayı kaliteli bir sağlık bakımı elde etmek için mücadele etmek zorunda kalmaktadırlar. Lezbiyen kadınlar heteroseksüellerle karşılaştırıldığında lezbiyenler koruyucu sağlık hizmetlerinden daha az yararlanmakta, sağlık sorunu ortaya çıktı̆̆ında tedaviyi geciktirmekte ya da sadece şiddetli semptomlarda yardım arama davranışı göstermektedir. Lezbiyen kadınların sağlık bakım hizmetlerine erişmesinde engel oluşturan hem hizmet verenlerden hem de sağlık bakım sisteminden kaynaklı bazı faktörler vardır. Bu nedenle bu özel ve farklı kadın grubunun sorunlarına yönelik sağlık çalışanlarının eğitilmesi gerekir. Sağlık çalışanlarının eğitilmesi, rehberliği ve desteği sayesinde lezbiyen çiftler ne istediklerine karar verebilir, seçimlerini savunabilir ve sağlik hizmeti almada daha istekli olabilirler.
\end{abstract}

Anahtar Kelimeler: Eşcinsellik, lezbiyen, sağlık eşitsizliği, hemşirelik, ebelik

\begin{abstract}
In today's world, there have been changes in attitudes towards homosexuals and increases in community's awareness of lesbians and their families, and thus homosexuality has begun to be a more acceptable lifestyle. However, when the use of preventive health services by lesbian women is compared with that by heterosexual women, it is seen that the former group still suffers significant levels of inequalities in benefiting from health care and is exposed to discrimination to a great extent. The comparison of lesbian women with heterosexual women in terms of benefiting from health services has revealed that the former group receives preventive healthcare services less, and that when they have health problems, they delay the treatment and display help-seeking behavior only when the symptoms become severe.There are several factors arising both from the health care system and from healthcare providers' attitudes which prevent lesbian women from accessing health care services. Therefore, health workers should be trained on the problems of lesbian women. Under the guidance and support of health workers who have received the training, lesbian couples can decide on what they want to, can defend their preferences and may be more willing to receive health care.
\end{abstract}

Key words: Homosexuality, lesbian, health inequalities, nursing, midwifery

\section{Giriş}

Lezbiyen (lesbian), kendi cinsine yönelik duygusal, fiziksel ve cinsel yönelimi olan kadınları ifade etmektedir. ${ }^{1}$ Lezbiyen kadınlar toplumda azınlık bir grubu oluşturmakla birlikte prevalansı değişebilmektedir. Yapılan çalışmalarda cinsel yönelim, cinsel davranışlar ve cinsel kimlik kavramlarına yeterince yer verilmemesi, yapılan çalı̧̧ma zaman ${ }^{2}$ ve lezbiyen ya da biseksüel tanı- mının nasıl yapıldığına bağlı olarak ${ }^{3}$ eșcinsel popülasyonunun nüfusu hakkındaki tahminler değişebilmektedir. Ayrıca toplumda cinsel yönelimini ifade eden kişilerin yaşadıkları ayrımcılık ve stigma deneyimlerinin paylașılması da bu poülasyonun gizli kalmasına yol açabilmektedir. ${ }^{4}$ Ancak özellikle 1990'dan sonra eşcinsel davranışların kabulüyle birlikte Amerika' da eşcinsel say1-

Geliş Tarihi/Received: 20-11-2015 / Kabul Tarihi/Accepted: 20-09-2016

a. Prof. Dr., İstanbul Üniversitesi Florence Nighingale Hemşirelik Fakültesi, İstanbul

b. Yrd. Doç. Dr., Cumhuriyet Üniversitesi Sağllk Bilimleri Fakültesi, Sivas

Sorumlu yazar /correspondence:Dilek Bilgiç;Cumhuriyet Üniversitesi, Sağlık Bilimleri Fakültesi, Sivas, e-posta: bilgicdilek@gmail.com

Atıf: Hotun SM, Bilgic D, Toplumda Eşcinsellere Yönelik Tutumlar ve Lezbiyen Kadınlarda Sağlık Eşitsizliği. HSP 2016; 3(3):216-225

To cite this article: Hotun SM, Bilgic D, Attitudes Towards Homosexuals in Society, and Health Inequalities Regarding Lesbian Women. HSP 2016; 3(3):216-225 
sında artış olmaya başlamıştır. ${ }^{4-6}$ Bu gün Amerika'nın \%99 eyaletinde eşcinsel çiftler yaşamaktadır. ${ }^{4}$ Türkiye' de cinsel yönelimli bireylerin toplumda baskı görmeleri nedeniyle cinsel yönelimlerini açıkça ifşa etmelerinden kaynaklı güçlükler nedeniyle ile lezbiyen, gey, biseksüel, transseksüellere (LGBT) yönelik Türkiye’yi temsil eden bir araştırma yapmak çokta mümkün değildir. ${ }^{7}$ Eşcinselliğin yaygınlaşmasıyla birlikte, eşcinsellere yönelik tutumlar değişmeye ${ }^{5,6}$ lezbiyen ve aileleri konusunda toplumun farkındalığı artmaya başlamıştır. ${ }^{8}$ Eşcinselliğin zaman içinde kabulünün artışında ve tutum ve davranışlarda ki değişimde yaşla birlikte yaşanan deneyimlerin, kültürel değişim ve prevalansdaki değişimin etkili olabileceği belirtilmektedir. Ayrıca sosyal normlar, cinsel davranışları etkileyen değerler, ekonomik ve sosyal faktörler, yaşanan bölge, rrk, dini inançlar ve eğitim düzeyi de eşcinselliğe karşı tutumlarda etkili olabilmektedir. ${ }^{5,6}$

Lezbiyen kadınların üreme sağlığı da dahil olmak üzere sağlık bakımına ilişkin çalışmalar 1990 öncesine kadar yeterli değildi. Ancak 19902000 yılları arasında önemli olmaya başlamıştır. ${ }^{9}$ Lezbiyen kadınlar toplumda görünmez olduğu için kadın sağlığı sadece heteroseksüel kadının sağlığı gibi tanımlanmaktadır. Sağlık çalışanları da cinsel yönelimi heteroseksüel olarak kabul ettiklerinde sağlık bakım hizmeti içinde de lezbiyen kadınlar görünmemektedir. ${ }^{10}$ Heteroseksüel kadınlarla kıyaslandığında lezbiyen kadınlar gerek koruyucu sağlık hizmetlerin kullanımında gerekse sağlık bakım hizmetlerinden yararlanmada önemli düzeyde eşitsizlikler yaşamakta, büyük ölçüde ayrımcılığa maruz kalmaktadır. Bu kadınların sağlık bakım arama davranışları daha azdır ve bireysel düzeyde yetersiz bakım almaktadırlar. $\mathrm{Bu}$ da rutin sağlık hizmetlerinden ve sağlık tarama hizmetlerinden yararlanmayı azaltmaktadir. $^{11}$

Araştırmalar lezbiyen ve biseksüeller tarafından sigara içme ${ }^{12-14}$ obezite ${ }^{15}$ ve tehlikeli düzeyde alkol tüketimi ${ }^{16,17}$ gibi riskli sağlık davranışlarının yaygın olarak yapıldığını göstermektedir. Riskli sağlık davranışları bu grupta kanser, koroner arter hastalığı, diyabet, hipertansiyon gibi sağlık sorunlarının gelişimini artırabilmektedir. ${ }^{18}$ Lezbiyen ve biseksüel (LB) kadınlarda bu risk davranışlarına katkıda bulunan olası diğer faktörler; cinsel azınlık olmanın yarattığı stigma, marjinal bir gruba ${ }^{19}$ ait olmayla ilişkili ortaya ç1kan strestir. Ayrıca eşcinsel kadınların daha fazla sağlik riskleri (örneğin; meme kanseri riski, koruyucu jinekolojik ve obstetrik bakım engelleri) ve engelleri söz konusudur. ${ }^{20}$
$\mathrm{Bu}$ derlemede eşcinsel bireylere yönelik tutumları ve lezbiyen kadınların karşı karşıya kaldığ 1 sağlık bakım eşitsizliklerini ve engellerini gözden geçirerek sağlık çalışanlarının bu konuya dikkatini çekmek ve farkındalık geliştirmek amaçlanmıştır.

\section{Eşcinsel Prevalansı}

Amerika Birleşik Devletleri'nde (ABD) ve dünya çapında toplum temelli yapılan çalışmalar lezbiyen, gey, biseksüel ve transeksüel (LGBT) nüfusunun büyüklüğü hakkında tahminen bir veri sağlamaktadır. Ancak yapılan çalışmalarda cinsel yönelim, cinsel davranışlar ve cinsel kimlik kavramlarına yeterince yer verilmemesi, çalışmanın yapıldığ 1 zaman ve lezbiyen ya da biseksüel tanımının nasıl yapıldığına bağlı olarak eşcinsel popülasyonunun nüfusu hakkındaki tahminler değişebilmektedir.

Brezilya'da kadınların \%4,9'unun lezbiyen, $\% 1,4$ 'ünün biseksüel olduğu saptanmıştır. ${ }^{21}$ İrlanda da 2006 yılında 7.441 kişiyle yapılan bir çalışmada da kadınların \%1.2'sinin eşcinsel ya da biseksüel olduğu belirlenmiştir. Çalışmaya kat1lan kadınların \%4,7'si yaşamlarının herhangi bir döneminde homoseksüel bir deneyim yaşadıklarını ifade etmişlerdir. ${ }^{22} \mathrm{Xu}$ ve ark. (2010) Amerika'da yaptıkları çalışmada kendini lezbiyen olarak tanımlayan kadın oranı \%19,1 olarak belirlenmiştir. ${ }^{23}$ Farklı yıllarda Avustralya (2005), Kanada (2005), İngiltere (2009-2010) ve Norveç (2010) olmak üzere 4 farklı ülkede yapılan toplumsal temelli çalışmada gey/lezbiyen oranı sırasiyla $\% 0,9, \% 1,1, \% 1,0$ ve $\% 0,7$ olarak bildirilmiştir. ${ }^{24}$ Aynı çalışmalarda ${ }^{24}$ ve Twenge ve ark. (2016) çalışmasında 6 kadınlar erkeklere oranla daha fazla kendilerini biseksüel olarak tanımlamışlardır. CDC (Centers for Disease Control and Prevention) 2014 y1lında Amerika Birleşik Devletleri cinsel yönelim ve sağlığı üzerine ulusal sağlık raporunu yayınlamıştır. 18-64 yaş grubu 33.500 kişiyle görüşülmüş ve bu grubun $\% 0,7$ 'si kendilerini lezbiyen olarak tanımlamıştır. ${ }^{4}$ Günümüzde artık lezbiyen çiftler de ebeveyn olmak istemektedirler. Amerika'da 650,000 eşcinsel çiftin \%19'unun 18 yaş altı çocuğa sahip olduğu tahmin edilmektedir. ${ }^{4}$

Türkiye de homoseksüellik alanında yapılan çalışmalar daha çok LGBT derneklerine üye olan eşcinsel ve biseksüellerle yapılan eşcinsellerin toplumda yaşadıkları sorunlara ilişkin çalışmalardır. $\mathrm{Bu}$ anlamda en son çalışma Türkiye'de LGBT Bireylerin Sosyal ve Ekonomik Sorunları Araştırması 2014 yılında Sivil Toplum 
Çalışmaları Merkezi (STÇM) ve Sosyal Politikalar, Cinsiyet Kimliği ve Cinsel Yönelim Çalışmaları Derneği (SPoD) ve Sosyal Politika Forumu (SPF) iş birliğiyle gerçekleştirilmiştir. Araştırma kendilerini LGBT olarak tanımlayan 2875 kişi gerçekleştirilmiş. $\mathrm{Bu}$ çalışmanın sonuçlarının cinsel yönelim ve cinsiyet kimliği temelli ayrımcılığın LGBT bireylerin yaşamlarında yarattığ sosyal ve ekonomik sorunlara ilişkin önemli ipuçları sunabileceği belirtilmiştir. ${ }^{7}$

\section{Eşcinsellere Yönelik Tutumlar}

Bazı toplumlar olumlu ve kabullenici tutumlara sahipken, çoğu toplumda eşcinsellere yönelik olumsuz tutumlar gösterilmekte, kötü muamele ve baskıya maruz kalabilmektedirler. Yapılan çalişmalarda 10 yetişkin Amerikalı' dan 6's1 eşcinsel ilişkilerin yasal olarak tanınması gerektiği düşüncesindedir. Ayrıca \%54 oranında homoseksüellik kabul edilebilir bir yaşam stili olarak görülmektedir. ${ }^{8}$ Twenge ve ark. (2016) Amerika'da eşcinsellik deneyimi ve tutmlarına yönelik yaptıkları ulusal düzeyde bir çalışmada 2014 yılına gelindiğinde, Amerikalıların yaklaşık yarısının (\%49) eşcinselliğin kötü olmadığına inandıklarını saptamıştır. ${ }^{6}$ Afrika'daki kabile toplulukları arasında, eşcinselliğin kabulü \%64'tür. ${ }^{25} 2004$ 'te yapılan toplum temelli bir çalışmada da homoseksüelliğin kabul edilebilir bir yaşam tarzı olduğuna inanan Amerikalı yetişkinlerin yüzdesinin 1981 yılında \%14 iken 2003 de \%46'ya yükseldiği gösterilmiştir. ${ }^{26}$

Türkiye'de yapılmış olan araştırmalara göre kadınlar erkeklere göre eşcinsellere ve biseksüellere karşı daha olumlu tutumlar sergilemektedirler. ${ }^{27-29}$ Ayrıca, eşcinsel/biseksüel bir tanıdığı olan ya da bu kişilerle sosyal ilişkide bulunan bireylerin, daha olumlu tutumlara sahip olduğu da görülmüsşür. ${ }^{27,29}$ Ancak Türkiye'de eşcinselliğe yönelik toplumsal algının, zaman içinde çokta büyük bir gelişme göstermediği düşünülmektedir. Türkiye'de eşcinselliği engelleyen yasalar yoktur; ancak medeni kanunda da "cinsel yönelim" gibi bir ifade de yer almamaktadır. Eşcinsellik yasal olarak bir suç olmasa da, siyasal iktidarlar eşcinselliği kamusal alanda ya yok saymışlar ya da eşcinsellere karşı düşmanca tavırlar sergilemişlerdir ${ }^{30}$ Yılmaz ve Göçmen' in (2015) LGBT kişilerle yaptıkları çalışmada LGBT'ler yaşamlarını idame ettirmeye yönelik en temel alanlarda bile ciddi ayrımci tutumlara maruz kaldıklarını bildirmişlerdir. Ayrımcılığa uğradığını bildiren LGBT'lerin çoğunluğu ise yasal yollara başvurmadıklarını belirtmişlerdir. Ya- sal yollara başvurmamalarının en önemli iki sebebi hukuka olan güvensizlikleri ve hukuki süreçlerde özel hayatlarının gizliliğine yeterli özenin gösterilmeyeceğine ilişkin kaygıları olmuştur. Yasal yollara başvuranların oğunluğu ise tatmin edici bir sonuç elde edemediklerini belirtmişlerdir. Bu sonuçlara göre araştırmacılar ülkemizde LGBT'lere yönelik yaşamın farklı alanlarında ayrımcılık yapıldığını, ancak bu ayrımc1lıkla etkin mücadele etme yollarının ise kısitlı olduğunu vurgulamışlardır. ${ }^{7}$

Cinsel konular dahil toplumsal önyarg1lar, doğru bilgilendirme olsa bile, çok yavaş ve güç değişir. Üstelik yanlış bilgilerle de pekişmesi daha yaygındır. Yapılan çalışmalarda eğitim düzeyi artışının eşcinsellere yönelik tutumları olumlu etkilediği; dindarlığın ise cinsel önyargıyı arttırdığı görülmüştür. Tanrı'nın verdiği cinsiyete uygun davranmayarak Tanrı'nın kurallarına karşı gelen kişiler olarak algılanan eşcinsellere yönelik olumsuz tutumların beslendiği saptanmıștır ${ }^{31}$

Eşcinsel kadın ve erkeklere yönelik önyarg1 konusunda en sik kullanılan kavramlardan biri homofobi (homophobia) terimidir. Homofobi eşcinsellere yönelik düşmanca tutumları içeren eşcinsellere/eşcinselliğe yönelik gerçek dışı bir korkuyu ifade etmede kullanılmıştır. ${ }^{32}$ Homofobik inanışlar da tüm önyargılar gibi toplumun her kesiminde yaygındır ve değişmeye dirençlidir. Homofobi, eşcinselliğe karşı yanlış ve eksik bilgilenmeden kaynaklanan, genellemelere dayanan, yeni bilgi ve anlayışlarla karşılaşıldığında değişmeye açık olmayan, olumsuz veya düşmanca tutum, bir önyargı olarak ta tanımlanabilmektedir. Birçok insan, eşcinselliği, kabul edilir erkek ve kadın davranışlarına tehdit olarak algılamaktadır. Kadınlık ve erkeklikten beklenenlerin birisini bile yerine getirmeme, toplumsal sistemlerin en önemli ayaklarından biri olan cinsiyet kimliklerini sarsma anlamına gelmektedir; bu da eşcinsel bireyleri ister istemez toplumun dişına itmektedir. Bunun temelinde ise kültürel ve sosyal normların heteroseksüellik dışındaki cinsel yönelimleri sapkınlık olarak tanımlaması ve dışlaması yatmaktadır. ${ }^{33} \mathrm{Bu}$ da eşcinsellere ilişkin olumsuz kalıp yarg1 ve tutumları tetiklemekte ve bunların korku, nefret, sözel ve/veya fiziksel şiddet ve tehditler seklindeki ayrımcı davranışlar olarak ortaya çıkmasına neden olmaktadır.

Genel olarak, bireylerin kendi cinsiyetlerinden olan eşcinsellere karşı daha olumsuz düşünce ve duygular besledikleri; bununla birlikte, erkeklerin, kadınlara oranla kendi cinsiyetinden eşcinsellere (geylere) karşı daha da olumsuz tu- 
tumlara sahip oldukları görülmektedir. ${ }^{34-36}$ Araştırmalar, eşcinsellere karşı geliştirilen olumsuz tutumların, eşcinseller ile toplumsal ilişkiye girildiğinde değişebileceğini belirtmektedirler. ${ }^{31,37}$ Bu anlamda, eşcinsel/biseksüel bireylerin toplum içerisinde daha görünür hale gelmeleri ve homofobik tutumlara sahip olan gruplarla daha sik ve olumlu sosyal ilişkiler kurmaları yararlı olabilir.

\section{Lezbiyenler ve Sağlık Bakımına Erișim}

Gey ve lezbiyen çalışmalarında en sık bahsedilen konulardan biri sağlık bakım hizmetlerine erișim konusudur. Bir toplumda stigma ve ötekileştirme deneyimleyen insanların sağlık hizmetlerine erişimi ve sonuçları arasında güçlü bir ilişki olduğu saptanmıştır. ${ }^{38}$ Lezbiyen kadınlar çoğunlukla hemşire ve diğer sağlık profesyonelleri arasında açığa çıkma korkusu ve homofobik tutumlardan dolayı kaliteli bir sağlık bakımı elde etmek için mücadele etmek zorunda kalmaktadırlar. ${ }^{39}$ Çoğu eșcinsel sağlık bakımına erişimi geçiştirebilmekte ya da geciktirebilmektedir. ${ }^{40}$ Yapılan çalışmalarda heteroseksüellerle karşılaştırıldığında lezbiyenlerin sağlık bakım hizmetlerinden daha az yararlandıkları, ${ }^{41}$ sağlık kontrollerini daha az yaptırdı $\breve{g}_{1}{ }^{42}$ ve aile hekimlerine daha az başvurduklar1 ${ }^{43}$ saptanmıştır.

İngiltere'de yapılan bir çalışmada da İngiliz sağlık bakım sisteminin cinsel yönelim gruplarına yönelik olumsuz algılarının olduğu bunun içinde personel eğitimi, farkındalık geliştirme gibi uygulamalarla sağlık bakım sisteminin geliştirilmesi gerektiği vurgulanmıştır. ${ }^{44}$ Lezbiyenler sağlık çalışanlarının olumsuz tutumları ve kültürel anlayış eksikliğinden dolayı sağlık bakım hizmetlerinden memnun olmadıklarını bildirmişlerdir. ${ }^{45}$ Elliott ve ark. (2015) lezbiyenlerin heteroseksüellere göre sağlık çalışanlarıyla daha olumsuz sağlık bakım deneyimlerinin olduğunu saptamıştır. ${ }^{46}$ Markus ve ark. (2010) lezbiyen annelerin lezbiyen jinekolog ve ebelerden bakım almayı desteklerken yine de ebeveynliklerine ilişkin endişelerini dinlemeye istekli, duyarlı, açık ve yargilayıcı olmayan ve tüm doğurgan kadınların heteroseksüel olduğu varsayımından kaçınan sağlık bakım profesyonellerini istediklerini bulgulamıştır. ${ }^{47}$

Kültürel yetkinlik, yaygın görülen sağlık eşitsizliklerini azaltmada bir yaklaşım olarak ifade edilmektedir. Sağl1k profesyonellerinin lezbiyen sorunlarına kültürel yetkinlik geliştirmeleri bu anlamda en önemli yaklaşımlardandır. Eşcinsel bireylere yönelik kültürel yetkinlik geliştirmede spesifik olarak eşcinsel bireylerin yaşadığ 1 sorunların ve sağlık eşitsizliklerinin farkında olabilmeleri için personelin bu konuda eğitilmesi, sağlık bakımı için başvuran bireyin cinsel yönelimi veya cinsiyet kimliği hakkında varsayımlarda bulunmaktan kaçınarak gerek iletişimde gerekse hastane dokümanlarında cinsiyet nötr bir dil kullanmak ve cinsel kimlik ve cinsel davranışların doğrudan sorularak, LGBT dostu semboller kullanılması eşcinsellerin sağlık bakım eşitsizliği yaşamasını azaltmada en önemli uygulamalar arasında sayılabilir. ${ }^{2,45,48}$ Sağlık profesyonelleri heteroseksüel hastalara olduğu gibi LGBT hastalar için de sicak ve saygilı bir ortam yaratmada gerekli adımları atabilmelidirler.

Eşcinsel kadınların sağlık gereksinimleri heteroseksüel kadınlarla benzerlik gösterse de bazı gereksinimler bu gruba özgü daha spesifiktir. Ancak lezbiyen ve biseksüel kadınların spesifik sağlık sorunları genellikle fark edilmez ya da çok dikkate alınmaz. Sağlık sigortası kapsamının yetersizliği ve sağlık personeliyle yaşanan olumsuz deneyimler sağlık bakımına ulaşmada yetersizliğin temel nedenleri olarak belirtilmektedir. Çoğu lezbiyen sağlık personelinin olumsuz tutum ve davranışından dolayı ve yetersiz sağlık hizmeti alma olasılığına karşı cinsel yönelimini açıklamaz. Sağlık personeli düşmanca yaklaşımlar gösterme, cinsiyetçi ve aşağılayıcı yorumlar yapma, bilgi vermeme, uygun olmayan imalarda bulunma ya da uygunsuz şakalar yapma, fiziksel temas kurmama ve uygunsuz ruh sağlığına yönelik tavsiyelerde bulunma gibi tutum ve davranışlarda bulunabilirler. ${ }^{3}$ Heteroseksist bakıșla "kadın Sağlığı" üreme ve heteroseksüel sağllk olarak düşünülmektedir. ${ }^{39}$

Hemşirelik alanında kültürün etkisini belirlemek için bazı ilerlemeler olsa da yapılması gerekenler hala vardır. Kadın sağlığının bakımında sosyal, politik, ekonomik faktörlerin yanı sira fiziksel, kültürel, emosyonel, sosyal ve spritüal yönlerde ele alınmalıdır Bireylerle ve ailelerle doğası gereği yakın iletişimde bulunan hemşireler bir sosyal adalet ajanı olarak ayrımcılığa uğrayan ve damgalanma yaşayan toplulukların pozitif yönde değişmelerinde çok önemli konumdadırlar.

Lezbiyen Kadınlarda Sağlık Eşitsizliği Bir toplumda sağlık bakım hizmetlerine ulaşımda değişim olduğunda, rutin tıbbi yardım aramada gecikme ya da hiç olmadığında, kalitesiz bakım alındığında ya da ayrımcı tedaviye maruz kalındığında o toplumdaki bireyler negatif sağlık sonuçları açısından risk altındadır. ${ }^{49}$ 
Son veriler eşcinsel popülasyonunun müdahale gerektiren çok sayıda sağlık riskleriyle karşı karşıya olduğunu örneğin, kadından kadına bakteriyel vaginosis, trikomonas, genital herpes, HPV, hepatit A, sifiliz ve HIV gibi enfeksiyonların geçişinin olabileceğini, göstermektedir. ${ }^{50-53}$ Jackson ve ark. (2016) eşcinsellerle yaptığı çalışmada sağlık sonuçları bakımından lezbiyenlerin heteroseksüellere oranla \%20 daha fazla obez olduklarını, \%17 daha fazla fonksiyonel sinırlılıkları olduğunu ve daha fazla paralizi yaşadıklarını saptamıştır. ${ }^{54}$ Ayrıca yapılan çalışmalarda cinsel azınlik grupların heteroseksüel bireylere oranla daha fazla anksiyete, depresyon, ${ }^{55}$ panik atak, psikolojik distres ${ }^{56}$ ve intihar düşüncesi yaşadıkları saptanmıştır. ${ }^{57}$ Yılmaz ve Göçmen'in (2015) ülkemizde yaşayan cinsel azınlık gruplarla yaptığı çalışmasında da ankete katılan LGBT bireylerin \% 50,3'ü (1447 kişi) cinsel sağlik hizmetlerine nereden ve nasıl ulaşabileceğini bilmezken, \% 43,2'si (1218 kişi) hayatında en az bir kez intiharı düşündügünü belirtmiştir. ${ }^{7}$ Buna karşın bazı faktörlerden dolayı eşcinsel kadınların sağlık bakım arama davranışları daha az, sağlık bakım hizmetlerine daha az ulaşmakta, bireysel düzeyde yetersiz bakım almakta ve rutin sağlık hizmetlerinden ve sağlık tarama hizmetlerinden yeterince yararlanmamakta dırlar. ${ }^{3,45}$

\section{Lezbiyen Kadınlarda Sağlık Eşitsizliğine Katkıda Bulunan Faktörler}

Lezbiyen kadınların sağlık bakım hizmetlerine erişmesinde engel oluşturan hem hizmet verenlerden hem de sağlık bakım sisteminden kaynaklı bazı faktörler vardır. ${ }^{3,57}$

Sağllk profesyonelleri ile ilgili faktörler: Heteroseksüellik varsayımı sağlık hizmeti ortamında çok yaygındır. Bakım standartları, öğretim materyalleri ve uygulama alanında kullanılan dil çoğunlukla heteroseksualite varsayımları üzerine temellidir. Sağlık çalışanlarının ayrımcılık yapması lezbiyenlerde güvensizlik yaratır ve lezbiyenlerin sağlık çalışanlarına kendilerini ifade etme olasılığını azaltır. ${ }^{3}$ Buna karşın sağ lık bakım ortamında lezbiyenlerin ya da eşcinsel bireylerin rahat olmaları, homofobik olmayan yaklaşımlar ve bireylerin cinsel yönelimlerini rahatlıkla açıklayabildikleri bir ortamın sağlanması, lezbiyenler arasında sağlı bakım hizmeti kullanımının önemli düzeyde artmasına katkıda bulunduğu saptanmıştır. ${ }^{58}$

Bakım verenlerin bilgisi ve duyarlılığı: Lezbiyenler arasındaki önemli bir endişe sağlık çalışanlarının lezbiyenlere ilişkin sağlık gereksinimleri ve yaşam stilleri ile ilgili farkındalık ve duyarlılık geliştirememiş olmalarıdır. ${ }^{3}$ Lezbiyen kadınlar sağlık çalışanlarının bilgi yetersizliklerinin farkındadırlar. ${ }^{59}$ Sağlık çalışanlarının lezbiyenler hakkındaki bilgisi, endişeleri ve tutumları önemlidir; uygun bir dil ve iletişim tarzının kullanımı; klinik yetkinlik; acil durumlarda hazır oluşluk; toplumun genelindeki lezbiyenlere ve kadın partnerlerine yönelik pozitif tutuma sahip olma ve lezbiyenleri ilgilendiren sorunlara karş1 duyarlı olma gibi. ${ }^{3}$ Genelde sağlık çalışanlarının kendilerine pozitif yaklaştığını algılayan lezbiyenlerin tedavi önerilerine ve kontrol izlemlerine uyması da daha fazladır. İletişim becerilerini geliştirmek ve cinsel yönelim konusunda yeterli bilgiye sahip olmak sağlık çalışanlarının lezbiyenlerin sağlığı için daha iyi bakım vermede gereken en önemli ilk adımdır. ${ }^{3}$

Güven sorunu, kabul etme: Başvuranın cinselliğinin farkında olmak sağlık çalışanının bireyin gereksinimlerini ve risklerini bütüncül anlayışla ele alması açısından önemlidir ve zamanında önerilerde bulunmayı ve uygun bakım vermeyi etkileyebilir. Örneğin kendi cinsel yönelimini sağlık çalışanına ifşa edenlerin son 2 yılda pap test sonuçlar $1,{ }^{60}$ erken tedaviye başvurma ve koruyucu bakım hizmeti alma oranı daha fazladır. ${ }^{3}$ Çoğu hasta gibi lezbiyenler de her defasında farklı sağlık çalışanına defalarca öyküsünü ifşa etmek zorunda kalmamak için aynı sağlık çalışanı tarafindan hizmet almayı tercih etmektedir. Açık ve güvenli görünen bir sağlı ortamı lezbiyenler için önemlidir, böylece cinsel yönelimlerini ve öykülerini rahatça ifade edebilme olasılıkları artar. Lezbiyenler güven duygularını geliştirmek için sağlık durumları için çeşitli koruyucu stratejiler geliştirdiklerini bildirmişlerdir. $\mathrm{Bu}$ stratejilerden biri ayrımcı olmayan, kabullenici ya da lezbiyen dostu olarak bilinen sağlık çalışanlarından bakım almak. Başka bir strateji de sağlık randevularına eşcinsel bireylerin ya da lezbiyenlerin yanında lezbiyen bir tanık getirmesidir. Bu nedenle lezbiyene partneri ya da arkadaşı da dahil tarafsız, kabullenici, rahat, güvenli ve konuksever ortamlar yaratmak sağlık bakım profesyonellerinin görevlerinden olmalıdır. ${ }^{3}$ Ayrıca sağlık profesyonellerinin destekleyici, sakin ve saygil1 yaklaşımları, bekleme odalarına ve muayene odalarına LGBT bireylerle ilgili materyallerin, broşür, poster, resim vb. konması ve sağlık profesyonellerinin bilgili olması bu grup kadınların cinsel yönelimlerini ifşa etmelerinde ve güven oluşturmada kolaylık sağlayabilecektir. ${ }^{57,60}$

Sağllk bakım profesyonelleri ile negatif ilişsile: Sağlık bakım profesyonelleri toplumsal 
önyargılara karşı duyarsız değildirler ve homoseksüaliteye ilişkin kendi kişisel inanç ve tutumları topluma verilen hizmetin kalitesini ve türünü etkileyebilir. Araştırmalar lezbiyenlerle sağlık profesyonelleri arasında anksiyete, düşmanlık, aşırı merak, aşağılayıcı espriler ve mental sağlığa yönelik uygun olmayan önerilerde bulunma gibi negatif etkileşimin olduğunu ortaya koymuştur. Sağlık hizmeti alırken sağlık profesyonelleriyle geçmişte uygunsuz, olumsuz etkileşim deneyimleyen lezbiyen oran $\% 72$, hekimlerle negatif etkileşim deneyimleyen lezbiyen oranının \% 77 olduğu saptanmıştır. Sağlık profesyonelleriyle negatif etkileşim sonrasında çoğu lezbiyen aşağılanmış hissettiklerini, öfkelendiklerini, korkutulmuş olduklarını, küçümsendiğini, savunmasız hissettiklerini, utandıklarını ve susturulduklarını ifade etmişlerdir. Üçte bir oranında lezbiyen cinsel yönelimlerini açıkladıklarında negatif reaksiyonlardan dolayı iletişimini sonlandırmak zorunda kaldıklarını belirtmiştir. ${ }^{3}$ Lezbiyen ve biseksüel kadınlar kendi sağlık ihtiyaçları hakkında bilgili, açık fikirli, cinsel yönelimini güvenle açıklayabilmesini teşvik edebilen eşcinsellere olumlu yaklaşan sağlık bakım profesyonelini tercih etmektedirler. ${ }^{45}$

Sağllk Bakım Sistemiyle İlgili Faktörler: Sağlık profesyonelinin eğitimi; Meslek olarak değerlendirildiğinde ülkemizde eşcinsellere yönelik olumsuz tutumlara sahip olan meslek grubu arasında sağlık profesyonellerinin olduğu saptanmıştır. ${ }^{62}$ Sağlık profesyonellerinin kültürel yetkinlik kazanması için alınan yetersiz eğitim, farklı popülasyonlardaki bireylerin ve hizmet alamayan bireylerin gereksinimlerini içermeyen eğitim programları bu grupların indirekt olarak eşitsizliğine katkıda bulunur. Dolayısıyla kurumsallaşmış önyargılar sağlık bakımında ayrımcılığın devamını kolaylaştırmaktadır. ${ }^{3}$ ABD'de tıp fakültesindeki derslerle ilgili yapılan bir araştırmada 1998 y1lında cinsel yönelimli bireylerin bakımına yönelik müfredat programında sadece 2,5 saatlik süre ayrıldığı belirlenmiştir. ${ }^{63}$ Gey ve lezbiyenlerin sağlık bakımını değerlendiren tıp öğrencileriyle yapılan benzer bir çalışmada da tıp ögrencilerinin \%40'1 geylerin sağlık sorunlarına yönelik verilen eğitimin yetersiz olduğunu düşünürken, \%68'i lezbiyen hastalara ilişkin ders müfredatında verilen eğitimi yetersiz olarak degerlendirmişlerdir. ${ }^{64}$ Kanada da tıp müfredatında bu konuya beş saatlik bir zaman ayrıldığı saptanmıştır. ${ }^{65}$

Cinsel yönelimli bireylerin sorunları ve bakımına yönelik konuların hemşirelik müfredatında yer alıp almadığına yönelik çalışmalar fazla değildir. Cinsel yönelimli bireylerin sorunları ve uygun bakımına ilişkin sağlık profesyonellerinin eğitimi çok önemlidir, sağlık profesyonelleri gey kültürüne yabancı olduklarında eşcinsellere bakım sunarken rahat olamadıklarını rapor etmişlerdir. Sağlık çalışanının rahatsızlığı lezbiyen kadınların sağlık bakımından yararlanmayı azaltıcı bir etkiye dönüşebilir. ${ }^{58}$ Tüm sağlık profesyonellerinin lisans eğitim müfredatlarında ve hizmet içi eğitim programlarında lezbiyen sağlık sorunlarına yönelik konuların ele alınması lezbiyen kadınların sağlık bakım sisteminde ötekileştirilmesinin azaltılması açısından önemlidir. Böyle bir eğitimde, lezbiyen kadınların spesifik sağlık bakım gereksinimlerini içeren bilgi, değerleri belirleme, ve iletişim becerilerinde duyarlılık gibi hem bilişsel hem de duyusal öğrenme alanları ele alınmalıdır. ${ }^{46}$ Bu konuda daha bilgili olan profesyoneller daha rahat ve daha yetkin bakım verebilecektir ve diğer sağlık çalışanlarına da rol modeli olabileceklerdir. ${ }^{3}$

Erişime ekonomik engeller; Lezbiyenlerin daha az sağlık sigortasına sahip olmaları ve gerekli sağlık bakım hizmeti ve ilaç alımlarında engellerle karşılaşmaları daha olasıdır. ${ }^{60,66} \mathrm{Ay}-$ rıca lezbiyen kadınlar heteroseksüel kadınlardan daha az gelire sahiptir ve bir lezbiyenin sağlık bakımı için daha az sağlık harcaması vardır.3 Lezbiyenler sağlık sigortasının yetersiz kaynağından dolayı koruyucu sağlık hizmetlerinden yeterli ya-

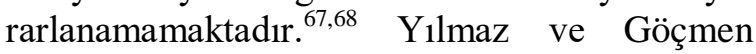
(2015) çalışmalarında ülkemizde aylık gelirini temel gereksinimlerini karşılamaya yetmediğini/zor yettiğini belirten LGBT oranı \%35 (987 kişi) olarak saptamışlardır. Aynı çalışmada \%23,9 (686 kişi) oranında kişi ruh sağlığı hizmetlerine ihtiyaçları olmasına rağmen, bu hizmetlerin pahalılığından dolayı hizmete ulaşamadıklarını, \%14,1 (400 kişi) kişi herhangi bir sağlık sigortası kapsamında olmadıklarını belirtmişlerdir. $^{7}$

Sağlık çalışanlarıyla deneyimlerde, iletişimde, erişimde heteroseksüel kadınlarla lezbiyenler arasında önemli düzeyde farkl11ıklar mevcuttur ve bu farklılıklar sağlık bakım hizmetlerini kullanımda tutarsızlıklara neden olmaktadır. Lezbiyen kadınlar heteroseksüellerle karşılaştırıld1ğında lezbiyenler koruyucu sağlık hizmetlerinden daha az yararlanmakta, bir sağlik sorunu ortaya çıktığında, tedaviyi geciktirmekte ya da sadece şiddetli semptomlarda yardım arama davranışı göstermektedir. ${ }^{68,69}$

Lezbiyen kadınlarin sorunlarl ve gereksinimlerine duyarl ve bilgili olmak, iletişim kur- 
mada becerikli ve uygun bakımı sağlamada yetkin olmak, kadınlara saygı duyulduğunu, kabul edildiğini hissettiren bir ortam sağlayabilmek ve ne olursa olsun cinsel yönelimli tüm kadınlara hoşgörülü olabilmek kadınlara sağlık bakımı veren tüm sağlık çalışanlarının sorumluluğundadır. Ayrıca sağlık çalışanları güncel bilgileri takip etmeli uygun koruyucu önlemler hakkında bilgili olmalı ve kadınların kolaylıkla ulaşabileceği uygun tarama ve koruyucu önerilerde bulunmal1dir. ${ }^{3}$

Hemşireler ve diğer çalışanlar misafirperver ve güvenli olan hem fiziksel hem de interaktif bir çalışma ortamı, yaratmak için çabalamalıdırlar. Örneğin "koca ya da erkek arkadaş" yerine partner ya da önemli bir kişi şeklinde kullanılmalıdır. Cinsel aktivite hakkında araştırmaya niçin böyle bir soruya gerek duyulduğunu açıklayarak başlanmalıdır. Heteroseksüaliteyi dikkate almayacak şekilde sorulmalıdır. Örneğin: kadınla, erkekle mi yoksa her ikisiyle de mi cinsel aktifsiniz? Hemşireler hastanın yanında ona eşlik eden her hangi bir olmadığında hastanın güvenliğini ve kabulünü sağlamada hemşireler hasta savunucu rollerini de uygulayabilirler. Farklı gruplara hitap eden okuma materyallerin ve resimlerin olması önemlidir. Bu değişimler sayesinde tehdit edici ve ayrımcı sağlık bakım ortamlarından güvenli ve kabul edici bakım ortamlarına dönüşebilir.

\section{Sonuç}

Lezbiyen kadınlar sağlık bakım hizmetlerinde eşitsizlik yaşamaktadır. Genellikle ayrımcılığa maruz kalmaktadırlar. Buda rutin sağlık hizmetlerinden ve sağlık tarama hizmetlerinden yararlanmayı azaltmaktadır. Sağlık profesyonelleri lezbiyenlerin sağlık sorunları, sağlık kuruluşlarındaki eşitsizlikler, eğitim, araştırma ve sağlık politikaları konularında farkındalıkların geliştirilmesinde önemli bir role sahiptir. Sağlık bakım profesyonelleri lezbiyen kadınların sağlık bakımını geliştirmede cinsel yönelim konularında kültürel yetkinlik geliştirmelidirler. Sağlık çal1şanları lezbiyen kadınları tanırken ve bütün kadınların heteroseksüel olmadığının farkında olduklarını göstererek gizlilikten kaçınarak açık olmalıdırlar.

\section{Kaynakça}

1. Gençlik Danışmanlık ve Sağlık Hizmet Merkezleri CSÜS Eğitimi Modülü: Katılımc1 Rehberi 2007. T.C. Sağlık Bakanlığı Ana Ço- cuk Sağlığ1 ve Aile Planlaması Genel Müdürlüğü. Ankara: Buluş Tasarım ve Matbaacılık Hizmetleri, 70.

2. Improving Cultural Competence To Reduce Health Disparities 2016. Agency for Healthcare Research and Quality U.S. Minnesota Evidence-based Practice Center Minneapolis, AHRQ Publicatio s.31-47 Available from: https://www.effectivehealthcare.ahrq.gov/ehc/products/573/2206/cultural-competence-report-160327.pdf

3. Hutchinson MK, Thompson AC, Cederbaum JA. Multisystem factors contributing to disparities in preventive health care among lesbian women. J Obstet Gynecol Neonatal Nurs. 2006; 35(3):393-402.

4. Blechinger DR. Understanding the LGBT communities. In: Eckstrand KL, Ehrenfeld J M.eds. Lesbian, Gay, Bisexual, and Transgender Healthcare. Springer International Publishing Switzerland 2016. p. 3-21.

5. Twenge JM, Sherman RA, Wells BE. Changes in American adults' sexual behavior and attitudes, 1972-2012. Arch Sex Behav. 2015; 44(8):2273-2285.

6. Twenge JM, Sherman RA, Wells BE. Changes in American Adults' Sexual Behavior and Attitudes, 1973-2014. Arch Sex Behav. 2016; 45(7):1713-1730.

7. Yılmaz, V. ve Göçmen, İ. (Haziran, 2015), Türkiye'de lezbiyen, gey, biseksüel ve trans bireylerin sosyal ve ekonomik sorunları araştırmasının özet sonuçları. Cilt IV, Sayı 6, s.94-101, Türkiye Politika ve Araştırma Merkezi (Research Turkey), Londra: Research Turkey (http://researchturkey.org/9142).

8. Newport F. Sixoutof 10 Americans say homosexual relations should be recognizedas legal. 2003. Gallup poll.. Available from: /http://www.galluppoll.com/content/?ci=8413andpg

9. Roberts SJ. Health care recommendations for lesbian women. J Obstet Gynecol Neonatal Nurs. 2006; 35(5):583-591.

10. Bailey JV, Farquhar C, Owen C, Whittaker D. Sexual behaviour of lesbians and bisexual women. Sex Transm Infect. 2003; 79(2):147150

11. Chetcuti N, Beltzer N, Methy N, Laborde C, Velter A, Bajos N, et al. Preventive care's forgotten women: life course, sexuality, and sexual health among homosexually and bisexually active women in France. J Sex Res. 2013; 50(6):587-597. 
12. .Fallin A, Goodin A, Lee YO, Bennett K. Smoking characteristics among lesbian, gay, and bisexual adults. Preventive Medicine. 2015; 74:123-130.

13. .Blosnich JR, Farmer GW, Lee JG, Silenzio VM, Bowen DJ. Health inequalities among sexual minority adults: evidence from ten U.S. states, 2010. Am J Prev Med. 2014; 46(4):337-349.

14. Cochran SD, Bandiera FC, Mays VM, Sexual orientation-related differences in tobacco use and secondhand smoke exposure among US adults aged 20 to 59 years: 2003-2010 National Health and Nutrition Examination Surveys. Am J Public Health. 2013;103(10):1837-1844.

15. Struble CB, Lindley LL, Montgomery K, Hardin J, Burcin M, Overweight and obesity in lesbian and bisexual college women. J Am Coll Health. 2010;59(1):51-56.

16. Hequembourg AL, Dearing RL, Exploring shame, guilt, and risky substance use among sexual minority men and women. J Homosex. 2013; 60(4):615-638.

17. Hequembourg AL, Livingston JA, Parks KA. Sexual victimization and associated risks among lesbian and bisexual women. Violence Against Women. 2013; 19(5):634-657.

18. Gonzales G, Przedworski J, Henning-Smith C. Comparison of health and health risk factors between lesbian, gay, and bisexual adults and heterosexual adults in the United States. JAMA Intern Med. 2016; Jun 27.

19. Meyer IH. Prejudice, social stress, and mental health in lesbian, gay, bisexual populations: conceptual issues and research evidence. Psychological Bulletin. 2003;129(5):674697.

20. Ridner SL, Frost K, LaJoie AS, Health information and risk behaviors among lesbian, gay, and bisexual college students. J Am Acad Nurse Pract. 2006;18(8):374-378.

21. Demographics of Sexual Orientation. Available from: http://en.wikipedia.org/wiki/Demographics_of_sexual_orientation\#United_States_2

22. Layte R, McGee H, Quail A, Rundle K, Cousins G, Donelly C, et al. The Irish studyof sexual health and relationships health among young people in Ireland main report. Dublin: Crisis Pregnancy Agency, 2006. Available from: http://www.ucd.ie/issda/static/documentation/esri/isshr-report.pdf.
23. Xu F, Sternberg MR, Markowitz LE. Women who have sex with women in the United States: prevalence, sexual behavior and prevalence of herpes simplex virus type 2 infection-results from national health and nutrition examination survey 2001-2006. Sex Transm Dis. 2010; 37(7):407-413.

24. Gates GJ, How many people are lesbian, gay, bisexual, and transgender? The Williams Institute 2011;1-9.

25. Fischer AH, Manstead A. The relation between gender and emotions in different cultures. In: Agneta HF, eds. Gender and emotion:Social psychological perspectives. 1 st. Ed. Cambridge University Press; 2000. p. 71-94.

26. Herek GM. Beyond “Homophobia”: thinking about sexual prejudice and stigma in the twenty-first century. Journal of NSRC. 2004;1(2):6-24.

27. Sakallı N, Uğurlu O. Effects of social contact with homosexuals on heterosexual Turkish university students attitudes towards homosexuality. Journal of Homosexuality. 2001;42 (1):53-62.

28. Güney N, Karg1 E, Corbac1-Oruc A. Universite öğrencilerinin eşcinsellik konusundaki görüşlerinin incelenmesi. 2004. Available from: http://www.hatam.hacettepe.edu.tr/74/.

29. Curakoğlu OC. Perception of homosexuality among Turkish University students: The role of labels, gender, and prior contact. The Journal of Social Psychology. 2006;146(3): 293-305.

30. Erdoğan B, Köten E. Yeni toplumsal hareketlerin sınıf dinamiği: Türkiye LGBT hareketi. Marmara Üniversitesi Siyasal Bilimler Dergisi. 2014;2(1):93-113.

31. Sakall1-Uğurlu N. Eşcinsellere ilişkin tutumlar: Türkiye'de yapılan görgül çalışmalar. Turk Psikoloji Yazıları 2006;9(17):53-69.

32. Herek GM. The psychology of sexual prejudice. In: Garnets LD, Kimmel DC (Editors). Psychological Perspectives On Lesbian, Gay, And Bisexual Experiences. Second Edition. New York: Columbia University Press; 2003. p.157-164.

33. Göregenli M. Gruplar arası ilişki ideolojisi olarak homofobi. Geylerin ve Lezbiyenlerin Sorunları ve Toplumsal Barış İçin Çözüm Arayışları. Ankara: Kaos GL Kitapları, 2004. s.142-148. 
34. Kite ME, Whitley Jr, Bernard E. Sex differences in attitudes toward homosexual persons, behavior, and civil rights: A metaanalysis. Personality and Social Psychology Bulletin 1996;22:336-353.

35. Harbaugh E, Lindsey EW. Attitudes toward homosexuality among young adults: connections to gender role identity, gender-typed activities, and religiosity. J Homosex. 2015;62(8):1098-125.

36. Anderssen N. Does contact with lesbians and gays lead to friendlier attitudes? A two year longitudinal study. J. Community Appl. Soc. Psychol 2002;12:124-136.

37. Sakallı N, Uğurlu O. Effects of social contact with homosexuals on heterosexual Turkish university students attitudes towards homosexuality. Journal of Homosexuality 2001;42(1):53-62.

38. Hatzenbuehler ML, Phelan JC, Link BG. Stigma as a fundamental cause of population health inequalities. Am J Public Health. 2013;103(5):813-821.

39. Weisz VK. Social justice considerations for lesbian and bisexual women's health care. J Obstet Gynecol Neonatal Nurs. 2009;38(1):81-87.

40. Fallin-Bennett K, Henderson S L, Nguyen GT, Hyderi A. Access to care. In: Eckstrand KL, Ehrenfeld J M.eds. Lesbian, Gay, Bisexual, and Transgender Healthcare. Springer International Publishing Switzerland 2016. p. 23-30.

41. Strutz KL, Herring AH, Halpern CT. Health disparities among young adult sexual minorities in the U.S. Am J Prev Med. 2015; 48:7688.

42. Buchmueller T, Carpenter CS. Disparities in health insurance coverage, access, and outcomes for individuals in same-sex versus different-sex relationships, 2000-2007. Am J Public Health. 2010;100:489-495.

43. Urwin $S$, Whittaker $W$. Inequalities in family practitioner use by sexual orientation: evidence from the English General Practice Patient Survey. BMJ Open. 2016; 6:e011633.

44. Stonewall. Unhealthy attitudes, the treatment of LGBT individuals within health and social care services. Stonewall, 2014.

45. McNair RP. Lesbian health inequalities: a cultural minority issue for health professionals. Med J Aust. 2003;16;178(12):643-645.

46. Elliott MN, Kanouse DE, Burkhart Q, Abel GA, Lyratzopoulos G, Beckett MK, Schuster MA, et al. Sexual minorities in England have poorer health and worse health care experiences: a national survey. J Gen Intern Med. 2015;30:9-16.

47. Markus EB, Weingarten A, Duplessi Y, Jones J. Lesbian couples seeking pregnancy with donor insemination. J Midwifery Womens Health 2010;55(2): 124-132.

48. Hart D. Toward better care for lesbian, gay, bisexual and transgender patients. Minn Med. 2013; 96(8):42-45.

49. Eliason MJ, Dibble S, Dejoseph J. Nursing's silence on lesbian, gay, bisexual, and transgender issues: the need for emancipatory efforts. Adv Nurs Sci. 2010;33(3):206-218.

50. Logie CH, James L, Tharao W, Loutfy MR. “We don't exist": A qualitative study of marginalization experienced by HIV-positive lesbian, bisexual, queer and transgender women in Toronto, Canada. J Int AIDS Soc. 2012;15:173-192

51. Steele LS, Ross LE, Dobinson C, Veldhuizen S, Tinmouth JM. Women's sexual orientation and health: Results from a Canadian population-based survey. Women Health. 2009;49:353-367.

52. Bradshaw CS, Walker SM, Vodstrcil LA, Bilardi JE, Law M, Hocking JS, Fethers KA, et al. The influence of behaviors and relationships on the vaginal microbiota of women and their female partners: The WOW Health Study. J Infect Dis. 2014;209:1562-1572.

53. 53. Muzny CA, Sunesara IR, Kumar R, Mena LA, Griswold ME, Martin DH, Lefkowitz EJ, et al. Characterization of the vaginal microbiota among sexual risk behavior groups of women with bacterial vaginosis. PLoS ONE. 2013;8:e80254.

54. Jackson CL. Agénor M, Johnson DA, Bryn Austin S, and Kawachi I. Sexual orientation identity disparities in health behaviors, outcomes, and services use among men and women in the United States: a cross-sectional study. BMC Public Health. 2016;16:807:111.

55. Lewis NM. Mental health in sexual minorities: recent indicators, trends, and their relationships to place in North America and Europe. Health Place.2009;15(4):1029-1045.

56. Cochran SD, Mays VM, Sullivan JG. Prevalence of mental disorders, psychological distress, and mental health services use among lesbian, gay, and bisexual adults in the United States. J Consult Clin Psychol. 2003;71(1):53-61. 
57. Fogel SC. Access to care. Internalized homophobia, disclosure, and health . In: Eckstrand KL, Ehrenfeld J M.eds. Lesbian, Gay, Bisexual, and Transgender Healthcare. Springer International Publishing Switzerland 2016. p. 39-47.

58. Bergeron S, Senn C. Health care utilization in a sample of Canadian lesbian wo men: Predictors of risk and resilience. Women \& Health 2003;37(3):19-35.

59. McNair RP, Anderson S, Mitchell A. Addressing health inequalities in Victorian lesbian, gay, bisexual and transgender communities. Health Promotion Journal of Australia 2001;11(1):305-311.

60. Diamant A, Schuster M, Lever J. Receipt of preventive health care services by lesbians . Am J Prev Med. 2000;19(3):141-148.

61. St Pierre M. Under what conditions do lesbians disclose their sexual orientation to primary healthcare providers? A review of the literature. J Lesbian Stud. 2012;16(2):199219.

62. Akdaş, M., and A. Tevhide 2008. "Eşcinsellere Yönelik Olumsuz Tutumlar: Meslek Grupları ve İlişkili Özellikler. Adli Bilimler Dergisi 7: 23-30.

63. United States Department of Health \& Human Services (USDHHS). Healthy People 2010 Companion Document for LGBT Health. 2000. Available from: http://www.glma.org/policy/hp2010/index.html.

64. McGarry K, Clarke J, Cyr M, Landau C. Evaluating a lesbian and gay health care curriculum. Teach Learn Med. 2002;14(4):244 248.

65. Obedin-Maliver, J., E. S. Goldsmith, L. Stewart, W. White, E. Tran, S. Brenman, M. Wells, D. M. Fettermen, M. Garcia, and M. R. Lunn. 2011. "Lesbian, Gay, Bisexual, and Transgender-Related Content in Undergraduate Medical Education”. Journal of the American Medical Association 306 (9): 971977.
66. Johnson MH, Henderson P. Acquiring and demonstrating attitudes in medical education: Attitudes to homosexuality as a case study. Med Teach 2000;22(6):585 - 591.

67. Cochran S, Mays V, Bowen D, Gage S, Bybee D, Roberts SJ, et al. Cancer-related risk indicators and preventive screening behaviors among lesbian women . Am J Public Health 2001; 91(4):591-597.

68. Marrazzo JM, Gorgos LM. Emerging sexual health issues among women who have sex with women. Curr Infect Dis Rep 2012;14:204-211.

69. Koh AS, Gomez CA, Shade S, Rowley E. Sexual risk factors among self identified lesbians, bisexual women, and heterosexual women accessing primary care settings. Sex Transm Dis. 2005;32(9):563-569. 